\title{
Climate Action Plan for the City of La Paz, BCS, Mexico: A Tool for Public Policy in a Coastal City
}

\author{
Antonina Ivanova1, Alfredo Bermudez-Contreras ${ }^{1,2}$ \\ ${ }^{1}$ Academic Department of Economics, Universidad Autonoma de Baja California Sur, La Paz, Mexico \\ ${ }^{2}$ Academic Department of Fisheries Engineering, Universidad Autonoma de Baja California Sur, La Paz, Mexico \\ Email: aivanova@uabcs.mx, abermudez@uabcs.mx
}

Received 18 July 2014; revised 23 August 2014; accepted 14 September 2014

Copyright (C) 2014 by authors and Scientific Research Publishing Inc.

This work is licensed under the Creative Commons Attribution International License (CC BY). http://creativecommons.org/licenses/by/4.0/

c) (i) Open Access

\begin{abstract}
As a result of its coastal location and severe water scarcity condition, the city of La Paz, Baja California Sur, Mexico, is extremely vulnerable to the impacts of climate change. This work presents the main findings of the Climate Change Action Plan for the City of La Paz and Neighbouring Areas (PACCLAP) including its development process and the main results of its two larger components: first, the vulnerability to climate change in the area and the adaptation measures suggested; and second, the local greenhouse gas emissions inventory and the recommended mitigation measures. In addition, the proposed actions have important impacts directly related with the Municipality Development Plan, thus making the PACCLAP a valuable instrument to support current and future decision makers in the formulation of public policies to foster a more sustainable development and improve the wellbeing of the local society.
\end{abstract}

\section{Keywords}

Public Policy, Coastal City, Climate Change, Inventory, Adaptation, Mitigation, Vulnerability

\section{Introduction}

The Climate Action Plan for the city of La Paz and surrounding areas originates as a complementary study to the Emerging and Sustainable Cities Initiative (ESCI) of the Inter-American Development Bank in which the city of La Paz in Baja California Sur (BCS) takes part. The ESCI seeks to help participating cities to identify the main challenges and the actions of short and medium term that allow guide their development towards greater sustainability. One of these challenges is the climate change in the first place, since the city is a main source of 
greenhouse gas emissions, which inventory allows to outline the actions to their mitigation, and, in the second place, due to the vulnerability to climate impacts on the key economic sectors and society of the city of La Paz (temperature variation, change of the coastline, saline intrusion into groundwater aquifers, hydrometeorological hazards, severity and redistribution of rainfall and drought, streambeds change, desertification, reduced availability of water for human and productive use, impacts on human, animal and plant health). The definition of the vulnerabilities allows establishing the main strategies and actions of adaptation to the impacts of climate change.

\section{Context of La Paz City}

La Paz city is the capital of BCS and is the seat of the municipality with the same name. The municipality has a population of 253,077 inhabitants and the $93.6 \%$ is concentrated in the towns along the coast. To the city of La Paz and surrounding areas the coasts of the Sea of Cortez are of great importance for the development, given that the activities that support the local people include maritime trade, fishing, tourism and services. However, agricultural activities are also developed in the valleys (Páez Rosas, 2007).

The city concentrates most of the government agencies, educational institutions and health centers in the state of Baja California Sur. From 1950 to 2010 the population of La Paz has steadily increased on average 4.5\% annually (INEGI, 2011a), which shows a community in motion by migration but also represents a challenge to achieve planning urban growth that promotes sustainable development.

The rapid population growth has led to a change in the city environment due primarily to the generation of waste, growth of the vehicle pool and deforestation (Ivanova \& Gámez, 2012). Likewise, poor urban planning has caused several pollution problems and increased greenhouse gas emissions (GEI).

The boundaries of the study area of this Plan of Action on Climate Change are shown in the map in Figure 1. Surrounding areas were included because of their influence on economic and social life of the city, as are particularly relevant in sectors such as transport and farming and fishing activities. The area of study and localities included were defined in consultation with officials from the City Council.

In the context of this study, the city is considered as an "urban ecosystem" (UNEP, 2008, 2011). It is studied from the perspective of natural resources management, and includes, therefore, surrounding areas that have a relation of mutual dependence with the city. The characteristics of the city of La Paz are the following: desert climate, coastal area, semi-arid zone, medium economic potential (most of the economic growth is on account of services, while the development of industry and agriculture is facing the strong constraint of water scarcity), high social development, medium size and medium population growth rate (4.5\% annual).

\section{Research Process, Training Workshops and Consultation Forums}

The research was conducted in two main modules: adaptation and mitigation, to cover the most important aspects for the city of La Paz related to the climate change. The components developed along the process were the following: 1) Adaptation: sea-level rise, water sector, desertification and biodiversity, economic sectors (livestock and agriculture, forestry, industrial, commercial, tourism, health and fishing), social vulnerability; 2) Mitigation: Greenhouse Gases Inventory: energy, industrial processes, solvent and other product use, land-use change and forestry, and waste. The study presents also the importance of environmental legislation, environmental education, capacity building and research in the area of climate change. Figure 2 summarises the stages of the project.

\section{Vulnerability and Adaptation}

In this study was applied, in a general manner, the methodology specified in UNEP (2008), Methodology for Assessment: GEO Cities. Manual for Application, Version 3; UNEP (2009), Training Manual on Vulnerability and Adaptation to Climate Change for Geo Cities, UN-Habitat (2010), Planning for Climate Change: A Resource Guide for Urban Planners (draft, 2010) y UNEP (2011) IEA Training Manual, Climate Change Vulnerability and Impact Assessment in Cities. However, it is important to mention that each component applied in addition its own methodology related to their specific area of study (water resources, sea-level rise, economic sectors, etc.).

The methodology assumes that sustainable development creates new demands regarding the impact assessment and structuring of response measures. In this regard, it is considered of importance:

- Recognize the interaction between environmental conditions and human activities;

- Take into account gender equity; 


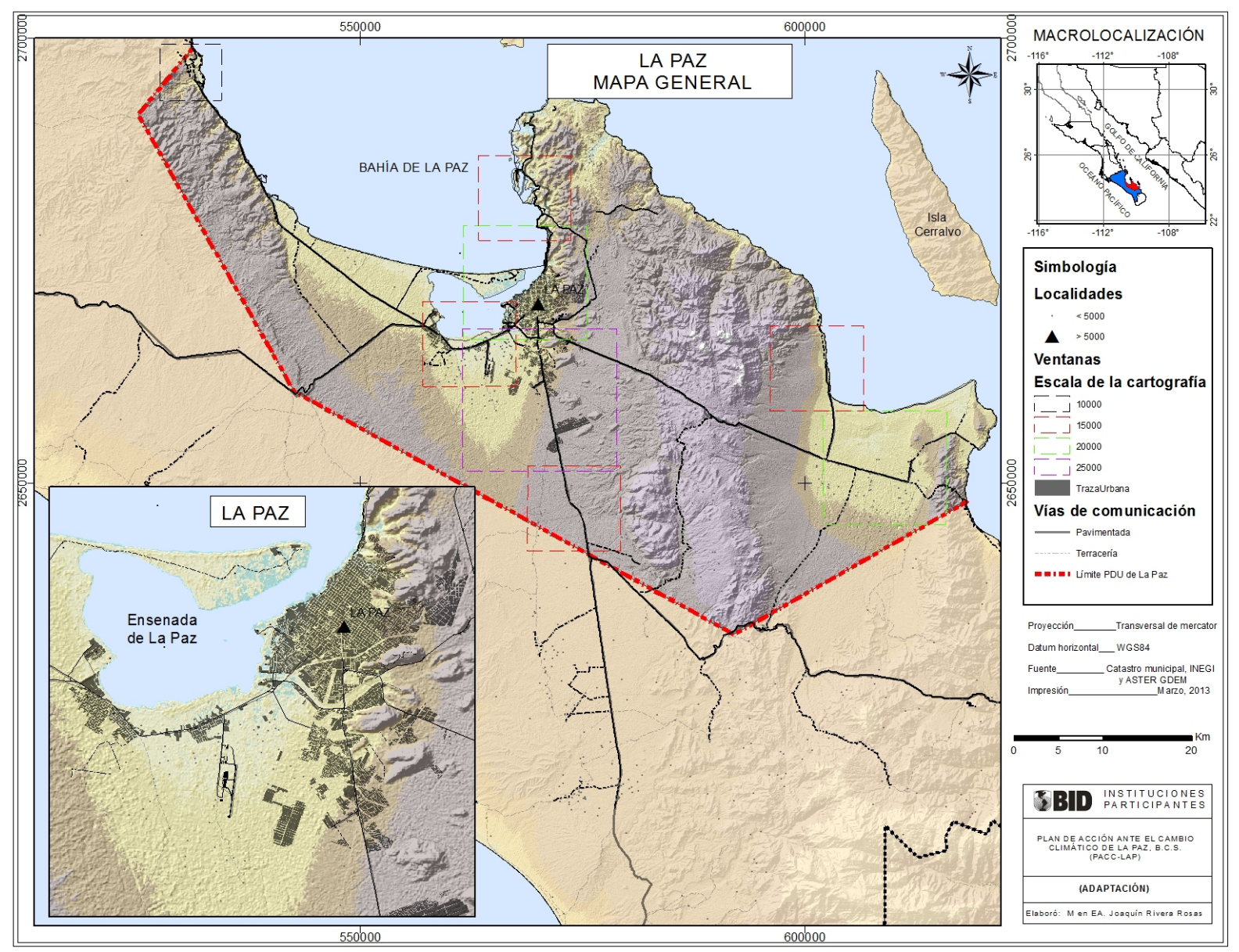

Figure 1. Map of La Paz city and surrounding areas: area of study.

- Take into account intergenerational equity;

- Promote the participation of the inhabitants of La Paz in decision-making.

The questions to answer are: What is the current environmental and socio-economic situation of the city of La Paz? How climate change impacts the environment and social welfare? What answers of adaptation could be proposed in the short and medium term?

\subsection{Current Situation and Impacts of Climate Change on the Environment and Social Welfare in La Paz}

The extreme vulnerability of the city of La Paz resulting from its geographic location and specific conditions, with main real and potential impacts of climate change, is recognized in the plan. By threatening water resources, causing stronger cyclones and floods, accelerating desertification, and negatively impacting biodiversity and marine and terrestrial natural populations, global warming increases the costs to maintain levels of comfort and security that allow undertaking productive activities and everyday life. These impacts have negative consequences on society and economy of the city: productive activities such as tourism, services, fishery and agriculture have to spend an increasing portion of its budget to counteract them; while other sectors such as livestock face higher production costs due to the lack of fodder because of water stress. Meanwhile, the population is affected by increased electricity costs, greater risks to public health and in extreme cases; and the local government faces greater pressure on its functions of attention to the inhabitants and economic sectors.

It should be noted that water stress is the greatest vulnerability for the city of La Paz. Nowadays the total amount of groundwater concession exceeds the sum of the water that is recharged annually to the two main aquifers of the study area (La Paz y Los Planes). The overexploitation of the aquifer of La Paz is recognized since 


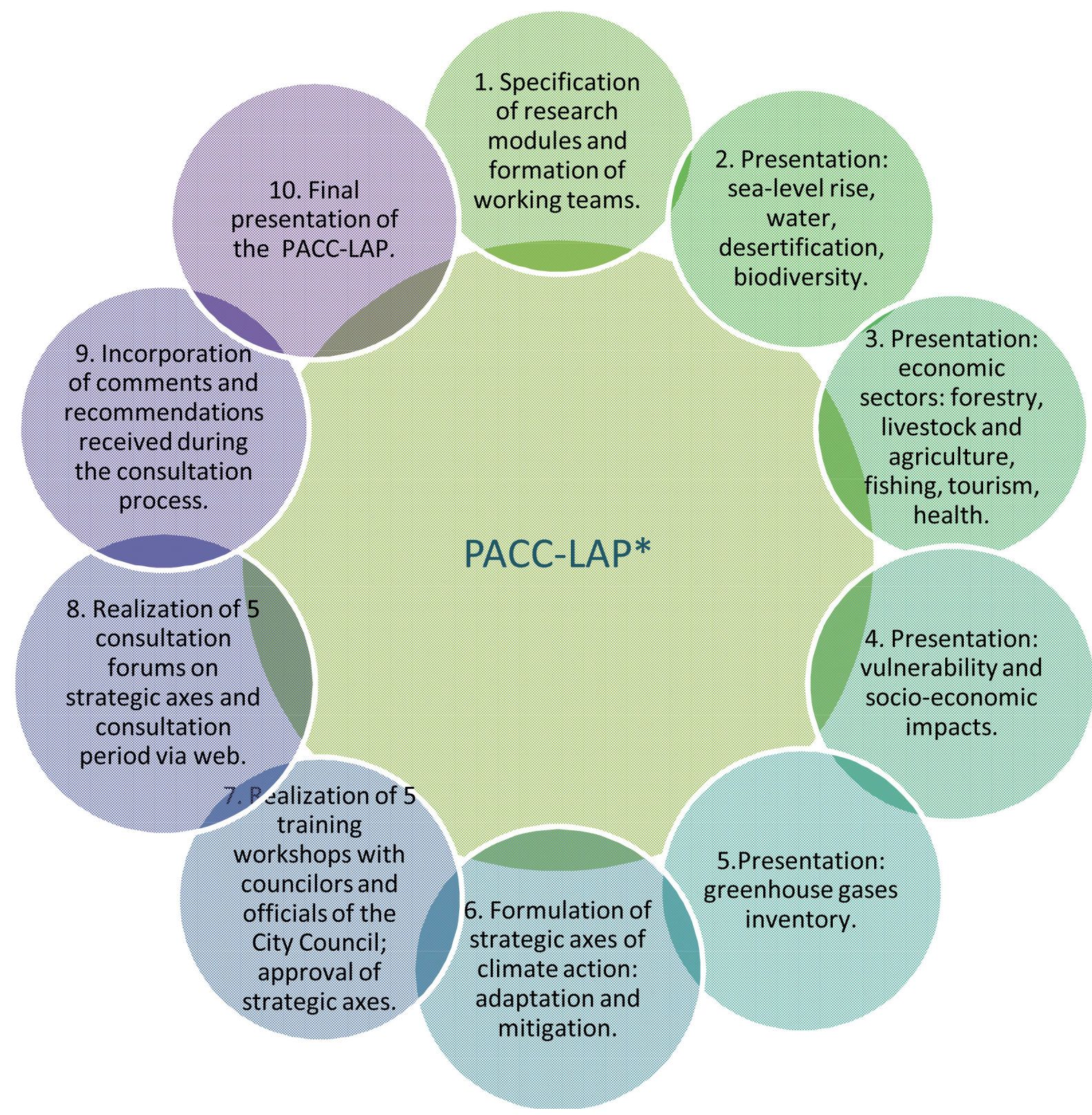

Figure 2. Stages of the process of research, trainingand consultation. *Climate Action Plan for the city of La Paz.

the 70’s (Troyo-Diéguez et al., 2010; CONAGUA, 2011), and the demand is increasing two times in the next 23 years due to population growth. The water consumption analysis in relation to temperature changes indicates that daily consumption rises 5.4 liters per person per each degree centigrade over the maximum temperature (CONAGUA, 2012).

Besides this threat, climate study shows potential increases in average sea temperature of about $1^{\circ} \mathrm{C}$ in the medium term as well as the extension of the summer (average temperatures of $27^{\circ} \mathrm{C}$ ) to the months of October and November (Ivanova \& Gámez, 2012; INECC, 2013). These phenomena will foster the intensification of cyclones and, in addition, its season could be extended, as it occurs during El Niño phenomenon, and generate more natural disasters (Wurl \& Martínez, 2006). The rise in sea level, according to data reported in this study between 5.4 $17.7 \mathrm{~cm}$ minimum and maximum respectively in 2030, and between $9-29.5 \mathrm{~cm}$ in 2050; is added and interacts with the magnitude of the storm surge, which may influence toward increasing these dimensions. The effects of this interaction in the long term will be of consideration for the city of La Paz and its surrounding areas, where the 
vulnerability index is high and the return period of hurricanes is small. This is because of the location of the poorest and most vulnerable populations, critical infrastructure (PMD, 2011) and main economic activities.

The study also characterize the patterns of urban growth and its direct relationship with the Change of Coverage/Land Use (CC/US) at a detailed scale in the area of La Paz, BCS, for which the multi-temporal analysis method was used to determine changes in land cover given by the growth of the urban area, using satellite images from 2005 and 2012, finding serious degradation of ecosystems in the urban area of La Paz, particularly in relation tourban expansion of the city as well as its impact on the biophysical environment. A deforestation rate of 1939 hectares of sarcocaule scrub, 7.57 hectares of mangroves and 11 hectares of vegetation in marshes and coastal dunes, was estimated for the period 2005-2012. The result was a total of 1957.5 hectares of deforestation in the area of La Paz in the studied period, that is to say, an annual deforestation rate of 279.65 hectares (0.11\%). The urban area of La Paz is growing in a disordered and dispersed manner, increasing the degree of unsustainability (Moreno Gómez, 2012). Because of the ecosystem fragmentation and increased urban and rural infrastructure greater vulnerabilityis generated by the constant human presence. Deforestation in the region of La Paz has been caused primarily by the development of agricultural activities and residential uses.

In agriculture, the increase in temperature and decrease in rainfall (OOMSAPA, 2012) will result immediately in increased water demand for each crop because of greater levels of evapotranspiration and soil salinization. Similarly, the increase in water demand would imply a higher energy cost. Moreover, in times of drought yields of some crops may decrease (SAGARPA, 2012), for example, 14\% in corn and $9 \%$ in sorghum. Also in periods of abnormal rainfall affectations of crops can be expected: $23 \%$ in corn and $15 \%$ in sorghum.

The industry sector is among the secondary activities of the state of Baja California Sur, which represents $26.61 \%$ of State GDP. Of these activities emerge mining, which contributes $2.96 \%$, construction and electricity, water and gas, which contributes $20.61 \%$, and manufacturing industry, 3.04\% (INEGI, 2010). The trade sector is among the most important tertiary activities in the state of Baja California Sur. Tertiary activities generate the greatest contribution to the State GDP, representing $69.50 \%$ in 2009. Of this percentage the following activities are released in order of contribution: commerce, hosting services and preparation of food and beverages (28.25\%), financial and real estate services (11.94\%), transport and information in mass media (10.62\%), in addition to educational and medical services $(7.26 \%)$ and government activities $(6.12 \%)$. By itself, the trade sector represents the sector with the greatest contribution to State GDP, with $19.1 \%$. Slightly less than a half of the employed population is employed in the retail trade sector, construction, hotels and restaurants. The retail trade has 4 times more employees supervised than the wholesale trade. Climate change may affect some of the commercial establishments located in areas at risk of flooding because of a rise in sea level and streambeds change due to higher rainfall. Also disruption of roads by heavy floods can affect the flow of supplies for a harmonious functioning of the trade sector.

In La Paz there are 347 establishments directly or indirectly devoted to tourism, from these $30 \%$ are restaurants, 18\% are hotels (INEGI, 2010). La Paz contributes 23\% of visitors to BCS. From 2008 to 2012 there was an average of 20,762 tourist arrivals. From the total of tourists received in La Paz $79 \%$ are national, while the remaining $21 \%$ are foreigners. The main foreign countries from which tourists come are the United States and Canada. The main reason for their trip is to visit relatives $32 \%$, rest $31 \%$, sport events $17 \%$ and conventions $10 \%$ (SECTUR, 2013). Tourism is the economic activity that although it belongs to the tertiary sector is highly vulnerable to climate impacts (similar to the economic activities from primary sector such as fishing and agriculture). This activity can be affected by the increase in average temperatures, which would make little attractive to tourists a greater period of the year (low season). On the other hand, some beaches could be affected by the rise in average sea levels. It is of importance to mention the influx of foreigners for full or part time residence, as well as the construction of marinas. However, more studies are needed to determine its contribution to income and employment creation in La Paz.

Health sector figures among tertiary activities, and represents, along with educational services, $7.26 \%$ of State GDP. In the state of Baja California Sur there are 144 public health care units with 1.543 doctors, and 14 private health care units with 44 doctors (INEGI, 2010). Of the total population of the municipality of La Paz (251.871), $75 \%$ is entitled to social security institutions. The frequency of suicide records was correlated with climatic variables. An increase in cases during spring-summer and decrease during autumn-winter was found. During warm season (May-October), the increase in temperature and suicide rates were positively correlated (Ivanova \& Gámez, 2012). It is important, therefore, to ensure greater public access to psychological care prophylactically. The municipality has 801 people who make up the medical staff. The medical staff is highly qualified and some hospitals 
have facilities and first class instruments. Likewise, there are medical institutions that make U.S. and Canada insurance valid. This is a factor benefiting the construction of second homes in the study area (Kiy \& McEnany, 2010). However, to promote second homes tourism it is necessary to invest in the quality of medical services and more first class hospital buildings in safe locations. Some health care units, such as the new ISSSTE hospital in Conchalito, are located in areas vulnerable to flooding. Therefore it is very important to do a proper planning for the construction of new medical units, taking into account the vulnerability to climate impacts.

\subsection{Adaptation Responses ${ }^{1}$}

To face the growing water scarcity there are a lot of technical methods to increase the supply, three of which have greater importance for the area of study: desalinization, reuse of treated wastewater and surface water catch in dams and reservoirs. These three alternative sources currently increase the supply of natural water in only about $20 \%$. In this connection, the following may be anticipated:

1) The reuse of treated wastewater is not a viable option for a substantial increase in water due to its relatively low volume and, in addition, most of this resource is already given in concession for irrigation.

2) Due to their high costs, desalination of brackish or salt water cannot replace the deficit expected in the near future (moreover, its impacts on the environment must be considered, since to do it fossil fuel is needed; however, solar energy can also be used).

3) The catch of surface water in dams, reservoirs or infiltration ponds represents the most viable option for La Paz, because of cost and efficiency.

4) For the city of La Paz there is also great potential for saving water by reducing leakage losses in the water system and through a more efficient consumption.

It is important to limit by legal means the human use of soil, water and vegetation, and animal resources present in areas of high diversity and high susceptibility to climate change located to the south of the cove of La Paz, La Ventana bay and in Sierra del Novillo (southeast of La Paz).

It is also essential to promote actions and campaigns to minimize loss of vegetation cover in the region, working together the various levels of government, civil society organizations, media and schools. The disappearance of woody vegetation and scrub not only modifies the composition of the resident animals communities, but local biogeochemical cycles, altering soil water retention and the recycling of nutrients essential for the functioning of ecosystems.

It will be necessary to promote adaptability of agricultural crops, seeking transformation towards those that are more resistant to sudden temperature changes, have a short life period, demand less water volume and are more profitable.

In the fisheries sector is relevant to open formal programs supported by scientific and technological information, which can diversify or change the capture of target species through the replacement of some existing procedures of artisanal commercial fishing, as well as investing municipal and private enterprise resources to carry out monitoring of the levels of catch and effort conducted in capturing sports-worthy fish species. It is feasible that like in the case of reef fish, pelagic eventually show changes in their composition. Such forecast will surely be reflected in the level of attraction that the sport will represent for tourism.

It is important to plan for future tourism development projects taking into account the average elevation of sea level and the potential flood areas because of high rainfall in hurricane season, as well as to plan the construction of new health and education institutions in areas not threatened by sea-level rise. The Urban Development Plan (UDP) must take into account, related to the growth of the city, the possible involvement of deforestation and affectation of groundwater recharge areas.

In general, for economic development is important to see the possibility of developing some additional industrial branches in La Paz, which help to create jobs and reduce excessive dependence on tertiary (tourism) and primary (fishing and agriculture) sectors, which are highly vulnerable to the impacts of climate change. However, their planning must take into account two important limitations: the scarcity of water resources, which will reinforce with the effects of climate change, and the small number of population.

The local media, schools and government agencies should conduct information campaigns directed to society about the dangers that climate change will bring to the residents of the municipality. These actions should be based primarily on the results of this research and other reliable information; environmental education needs to

\footnotetext{
${ }^{1}$ In this section the main adaptation actions are synthesized. The more specific and detailed proposals are available in the Core Strategies of Climate Action(see Ivanova et al. (2013)), which were designed based on research conducted for this Plan.
} 
be focused on all members of the South Californian society: farming and fishing communities, schools, parents and public officials, to name some. An adequate knowledge of the current situation and the one forecasted will be the only way people see as own the need to adapt to future conditions for their own benefit and that of their families.

\section{Mitigation}

As a first step to formulate recommendations aimed at reducing the greenhouse gas emissions (GHGE) of the study area, an inventory was carried out for years 2005 through to 2010. On this basis, the emissions in a business-as-usual (BUA) scenario for GHGE were calculated covering a period up to year 2030. This scenario provided a reference baseline to compare the effects of the GHGE mitigation recommendations. The results obtained in this process are presented next.

\subsection{Inventory and Baseline}

The local greenhouse gas emissions inventory (LGHGEI) was carried out following the revised 1996 Intergovernmental Panel on Climate Change's guidelines for greenhouse gas inventories (IPCC, 1997a; IPCC, 1997b; IPCC, 1997c). These guidelines cover six categories: Energy, industrial processes, solvent and other product use, agriculture, land-use change and forestry, and waste.

In the estimation of the city's emissions, the best resolution data available were used (state, municipal, local). For cases where available data did not correspond to the city itself, proxy indicators were calculated to enable an estimation of the actual city data.

The results of the inventory are presented in Table 1. In this Table, the far right column shows the combined total emissions for all categories for each year; the rest of columns show the emissions corresponding to every category and subcategory considered. As expected, emissions are dominated by the Energy category with more than $90 \%$ of the combined total.

The 2030 baseline under the BAU scenario was generated considering the official population growth projections from CONAPO (Mexico's National Population Council) for the whole state. This assumed a scenario where emissions increase proportionally to population growth only. Likewise, it was assumed that the city's population growth is proportional to the state's population. With this in mind, the emissions baseline was estimated using a per capita emissions factor resulting from averaging the per capita emissions for years 2005-2010. The baseline obtained is presented in Figure 3.

\subsection{Mitigation Recommendations}

As shown in Table 1, the largest share of emissions for La Paz and surrounding areas (LAPSA) corresponds first, to transport, and second, to electricity generation. It was then these categories that mitigation recommendations were primarily focused on.

\subsubsection{Transport: Current Situation in the State}

As of 2010, transport infrastructure in the municipality of La Paz comprised $1704 \mathrm{~km}$ of highways and roads, $1019 \mathrm{~km}$ of which are actually paved or have some kind of seal. There are also three mayor ports and one of the three international airports in the state.

Regarding the vehicle fleet, BCS is the state with the largest number of motor vehicles per person in Mexico. This number has grown rapidly in the last decade (see Figure 4) and for 2008 this number equalled 78 vehicles per 100 inhabitants, considerably higher than the national mean of 26.5 vehicles for 100 inhabitants (World Bank, 2013). It is not surprising then that between 2005 and 2010 approximately 75\% of transport fuels consumed in the state correspond to gasoline and diesel fuel. This has impacts on the state's and local transport emissions, which are dominated by these two fuels.

In addition to the large number of vehicles per inhabitant in the state and study area (LAPSA), the vehicle fleet is very old. An analysis of the LAPSA vehicle registrations shows that more than $80 \%$ of total registered vehicles are older than 10 years (although there is no certainty as to how many of them are actually in circulation). Undoubtedly, this has a negative effect on the fuel efficiency of the local vehicle fleet, and therefore, on the corresponding GHGE. The analysis of the registrations also showed that about $75 \%$ of registered vehicles were second hand vehicles imported from the United States (US), which is a very common practice in BCS and 
Table 1. LGHGEI including BAU data for 2020 and 2030.

\begin{tabular}{|c|c|c|c|c|c|c|c|c|c|c|c|c|c|}
\hline & \multirow{3}{*}{ Population } & \multicolumn{12}{|c|}{ Greenhouse gas emissions in $\mathrm{Gg}$ of $\mathrm{CO}_{2}$ equivalent $\mathrm{BAU}$} \\
\hline \multirow[t]{2}{*}{ Year } & & \multicolumn{4}{|c|}{ Energy } & \multicolumn{3}{|c|}{ Industrial processes } & \multirow{2}{*}{$\begin{array}{c}\text { Solvent } \\
\text { and other } \\
\text { product use }\end{array}$} & \multirow{2}{*}{$\begin{array}{c}\text { Agriculture } \\
\text { Subtotal }\end{array}$} & \multirow{2}{*}{$\begin{array}{c}\text { Land-use } \\
\text { e change and } \\
\text { forestry }\end{array}$} & \multirow{2}{*}{$\begin{array}{l}\text { Waste } \\
\text { Subtotal }\end{array}$} & \multirow[t]{2}{*}{$\begin{array}{c}\text { Annual } \\
\text { total }\end{array}$} \\
\hline & & Electricity & Transport & LPG & Subtotal & $\begin{array}{c}\text { Road } \\
\text { paving } \\
\text { (asphalt) }\end{array}$ & $\begin{array}{c}\text { Fugitive } \\
\text { refrigerant } \\
\text { emissions }\end{array}$ & Subtotal & & & & & \\
\hline 2005 & 196,685 & 381 & 633 & 57 & 1071 & 1 & 2 & 3 & 0 & 21 & 10 & 77 & 1182 \\
\hline 2006 & 202,244 & 435 & 637 & 59 & 1131 & 1 & 2 & 3 & 0 & 22 & 10 & 77 & 1243 \\
\hline 2007 & 207,803 & 390 & 757 & 61 & 1208 & 1 & 2 & 3 & 0 & 22 & 10 & 84 & 1327 \\
\hline 2008 & 213,362 & 469 & 763 & 60 & 1292 & 3 & 2 & 6 & 0 & 22 & 10 & 82 & 1413 \\
\hline 2009 & 218,921 & 504 & 711 & 53 & 1268 & 2 & 2 & 5 & 0 & 23 & 10 & 78 & 1384 \\
\hline 2010 & 224,480 & 497 & 722 & 52 & 1271 & 2 & 3 & 5 & 0 & 23 & 10 & 74 & 1383 \\
\hline 2020 & 308,172 & 651 & 1030 & 83 & 1765 & 3 & 3 & 6 & 0 & 32 & 15 & 115 & 1933 \\
\hline 2030 & 382,595 & 808 & 1279 & 104 & 2191 & 3 & 4 & 7 & 0 & 40 & 19 & 143 & 2400 \\
\hline
\end{tabular}

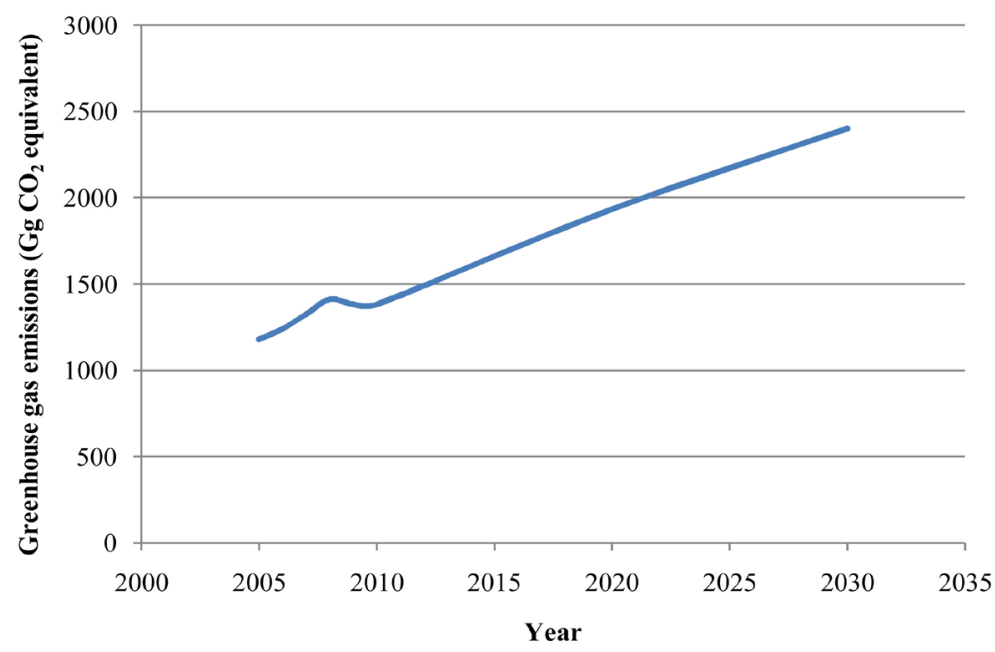

Figure 3. Greenhouse gas emissions baseline to 2030.

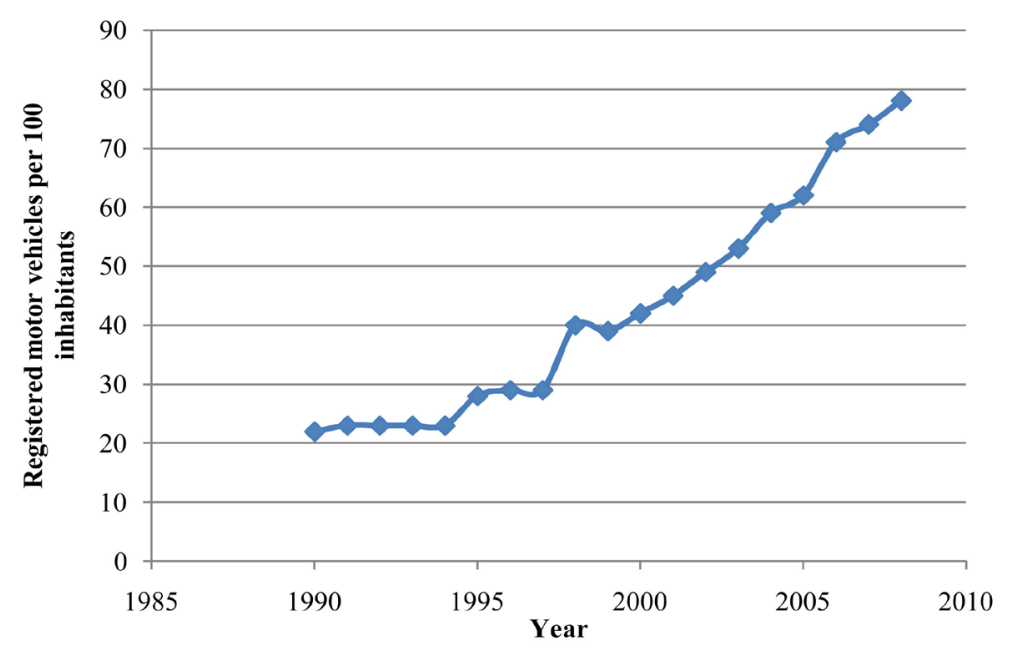

Figure 4. Registered motor vehicles in circulation for every 100 inhabitants in BCS. Source: Authors' elaboration with data from (INEGI, 2011b). 
other states close to the US border in Mexico.

\subsubsection{Transport Emissions Mitigation}

The effect of a vehicle replacement program aiming at improving the local fleet's fuel efficiency was considered first.

The evolution of the fuel efficiency of light duty vehicles during the past two decades in countries like Spain, France, Sweden, Australia, Germany, Netherlands, Italy or Japan has shown a clear improvement (IEA, 2009: p. 124). A fleet renovation program to achieve fuel efficiency improvements similar to those found in the countries mentioned above (1.2\% annual improvement) could have an important effect on terrestrial transport GHGE (gasoline and diesel fuel accounted for 79\% of transport GHGE during 2010). This program should not only consider old-for-new replacements but also provide incentives to replace internal combustion engine vehicles with different technologies such as plug-in hybrids and electric ones, especially in light of the large local potential for renewable electricity generation. If the program started in 2015, a $20 \%$ emissions reduction from terrestrial transport could be achieved by 2030 .

However, in this proposal it is of utter importance not to overlook the great ease that prevails in the region to purchase and import into Mexico second hand vehicles coming from the United States without undergoing a proper road worthiness inspection that guarantees good environmental and mechanical performance of the vehicles entering the country. Consequently, if implemented, this program should be very carefully devised so as to avoid substitution of current vehicles with others in similar conditions. It seems therefore necessary to find a suitable procedure that ties up the vehicle fleet renovation with fuel efficiency goals and controls as well as with operation condition of the replacement vehicles. This may require reforms to the actual Transport Law to enforce a strict mechanical, road worthiness and vehicle emissions inspection for people to maintain their vehicle registration and be allowed to circulate on the roads, especially for imported, second hand vehicles.

\section{Other Measures in Transport}

Local culture also plays a very important role in the use of motor vehicles, particularly regarding private vehicles and the (low) use of public transport. In this area, environmental education and direct work with people can have large contributions to change current local transport paradigms and, in turn, translate into GHGE reductions.

In addition, the development of new residential areas located along the city's access roads (radial growth) increases transport distances and encourages the use of private motor vehicles. This also results in higher emissions. An alternative urban growth model could also aid in the reduction of transport GHGE.

Finally, one more option to reduce local transport emissions (with the associated benefits for public health and life quality in general) is the use of alternative ways of transport like cycling or walking. However, for this to have a significant contribution to GHGE reduction, the number of cyclists and pedestrians must increase very significantly. In turn, this goal demands adequate infrastructure. This includes, for instance, cycling lanes clearly marked and with adequate signposting ${ }^{2}$, tree-shaded ${ }^{3}$ ways and wide pedestrian footpaths, amongst others. In parallel, appropriate regulation regarding the use of such infrastructure and also the provision of additional similar spaces in the future as well as established maintenance schedules is also required. Likewise, procedures must be put in place that guarantee a respectful use of these spaces by all members of society. Unfortunately, at the time of writing there is no regulation regarding cycling lanes in the municipality.

\subsubsection{Electricity: Current situation}

Electricity generation in LAPSA had the second largest emissions volume after transport with an average of 0.89 $\mathrm{kg} \mathrm{CO}$ equivalent per $\mathrm{kWh}$ of electricity consumed (average for 2005-2010). This factor is significantly above the national average for 2010 (0.58 $\mathrm{kg} \mathrm{CO}_{2}$ equivalent per kWh (SEMARNAT \& INECC, 2012: p. 271)). The high emission factors found locally are explained by the fuels used in electricity generation, heavy fuel oil no. 6 (bunker fuel) and diesel oil, which result in greater emissions than other fuels (e.g., natural gas, low-sulphur diesel fuel) or non-combustion generation technologies used elsewhere in the country (hydro, geothermal, nuclear).

\footnotetext{
${ }^{2}$ At present there are three cycle paths in the city, two of which are in a very poor state of maintenance and, in many places, also invaded by nearby commercial establishments and public infrastructure (bus stops, signposts, advertising, electricity and water infrastructure).

${ }^{3}$ Given the importance of trees as carbon sinks and the local climate, it would be beneficial to undertake a study to determine which of the local tree species have larger capacity to act as $\mathrm{CO}_{2}$ sinks that also need little water. This would reinforce the local Parks and Gardens Regulation that dictates what species are allowed to be used in different spaces according to size. Such a study would increase the impact of parks and public spaces as carbon sinks.
} 
Amongst the options to mitigate the electricity generation GHGE in LAPSA three categories can be identified:

- Improve the efficiency of the technology currently in use to achieve a lower carbon intensity of the electricity generated.

- Introduce other fossil-fuel-based generation technologies with cleaner fuels than those currently in use.

- Introduce generation technologies based on renewable energy that do not result in GHGE during operation.

Regarding the first category, the combined average efficiency of all power stations in BCS (mostly internal combustion engines and steam turbines) for 2010 was estimated at $38 \%{ }^{4}$. Given the technologies used, significant efficiency improvements are not viable.

Regarding the second category, combined cycle gas turbines could significantly improve generation efficiency. These plants have efficiencies in the range of 55\%, which would undoubtedly contribute to reduce the electricity generation emissions due to both, using a cleaner fuel and a more efficient process. However, natural gas is not currently available in the state nor is there any infrastructure in place to handle it. Present plans and programs (CFE, 2012; CFE, 2014) consider starting generation with natural gas in the mid-term future. Likewise, an electrical connection with the rest of the country (the state grid is at present isolated from the national grid) is also under consideration. However, both these options are very capital intensive and their results regarding GHGE reductions would be available in the mid and long-term future.

From the GHGE mitigation standpoint in the short term, an option with higher potential to achieve significant reductions is through the generation based on clean, local and renewable energy sources. For LAPSA, solar energy has the largest potential ${ }^{5}$.

\subsubsection{Grid-Connected Systems}

While off-grid rural solar electricity systems have been regularly installed throughout the state during the past two decades, with the issue of the first interconnection model contract in 2001 (and subsequent modifications) and the Law for the Exploitation for Renewable Energies and Financing the Energy Transition in 2008, it is now also possible to install and grid-connect private electricity generation systems based on renewable energy, including solar photovoltaics (PV). Harnessing PV electricity within CFE's networks (CFE is state-owned and sole power provider in Mexico), where most electricity consumption takes place, can be increased in the near future through the installation of distributed small and medium scale PV systems as well as through the installation of centralised large scale plants in the megawatt capacity range. Electricity generation through these schemes has been recommended to reduce emissions.

\subsubsection{Emissions Mitigation through Grid-Connected Systems}

1) Self-Consumption Small and Medium Scale Systems

In order to assess the mitigation potential of these systems, a bold scenario considering the implementation of incentive programs to install solar systems has been suggested. Such a scenario proposes that small and medium scale systems supply $20 \%$ of electricity consumption in LAPSA by 2030. Calculations assume that every $1 \mathrm{~kW}$ of PV panels installed in LAPSA will generate $1825 \mathrm{kWh}$ on a yearly basis which will offset the same amount of conventional generation ${ }^{6}$. The average emissions factor mentioned above ( $0.89 \mathrm{~kg} \mathrm{CO}_{2}$ equivalent per $\left.\mathrm{kWh}\right)$ was used to estimate the volume of offset GHGE. The combined power of all installed PV systems to achieve the $20 \%$ goal by 2030 is $100 \mathrm{MW}$.

2) Self-Consumption in Large Commercial and Public Buildings

In Mexico, larger consumers also have the possibility of installing renewable energy systems and connecting them to the grid to offset their consumption from the grid and their carbon footprint. These systems can be up to $500 \mathrm{~kW}$ in medium voltage without requiring a permit from CRE (the energy regulator), which is necessary above this limit.

\footnotetext{
${ }^{4}$ Based on the amount of fuel used (20537TJ) and the electricity generated (2147 GWh).

${ }^{5}$ Potential wind power sites have been identified on the boundaries of the study area. However, resource assessment studies are still to be undertaken to determine their actual quality of the wind resource. Likewise, biogas production for electricity generation from municipal solid waste and wastewater treatment is also a possibility. However, preliminary figures indicate a very small resource relative to the city's electricity demand. Therefore, mitigation recommendations could be more effective if directed elsewhere.

${ }^{6}$ It is known that due to the fluctuating nature of solar electricity, the local utility would need conventional "backup" generation capacity on standby if large amounts of solar electricity were in operation. Such backup could negatively affect the 1:1 generation offset ratio assumed in this work. However, on the other hand, on-site generation by grid-connected PV systems reduced transmission, distribution and transformer losses, which also impact on the offset conventional electricity ratio but in the opposite direction. It was expected that these two effects would counteract each other to a good extent.
} 
Local commercial establishments have already started taking advantage of this scheme and organisations like Soriana (2013) (a Mexican supermarket chain) recently announced their first Solar Photovoltaic Energy Project. In the first phase, they will install $500 \mathrm{~kW}$ of PV panels on the rooftop of three of their La Paz stores, with an expected annual generation of $880000 \mathrm{kWh}$, which equates to $25 \%$ of each store's consumption. With this generation an estimated $2.3 \mathrm{Gg}$ of $\mathrm{CO}_{2}$ equivalent would be offset annually.

This could also be the case of public buildings like the La Paz municipality's offices, where there currently is a plan to install a solar roof over their parking lot totalling around $1 \mathrm{MW}$ of PV panels to reduce their grid consumption. Such an installation could result in an electricity consumption reduction of some $1825 \mathrm{MWh}$ a year, and also a reduction of $1.6 \mathrm{Gg}$ of $\mathrm{CO}_{2}$ equivalent. This plan could be extended to include also the energy used for public services like waste and drinking water pumping and public lighting.

If other large commercial establishments and public buildings undertook similar initiatives, the conventional electricity demand could be significantly reduced. Assuming that other larger consumers in LAPSA installed 1 MW of PV panels for self-consumption adding one new such system every year, by 2030 there would be 18 MW of additional clean generation capacity besides what is already installed. Such consumers could include public buildings like schools, hospitals and larger hotels located in the area. It would be also expected that by 2030 there would be more commercial establishments and public buildings that could take part in such projects.

3) Small Producer-PV Power Stations

The counterpart of distributed systems like those mentioned above is centralised systems. During 2012 and the first trimester of 2013 the energy regulator in Mexico granted four permits for solar PV electricity generation in the area of La Paz under the Small Producer scheme (CRE, 2012a; CRE, 2012b; CRE, 2013a; CRE, 2013b). All of these have capacities ranging between 25 - 30 MW.

Considering the electricity each of these projects will generate according to their permit, their combined annual total amounts to $224 \mathrm{GWh}$. This equates to just over $10 \%$ of the electricity generated in 2010 in the whole state and about $40 \%$ of the electricity consumed in LAPSA in the same year. If all four of them were to be completed, they could offset up to $200 \mathrm{Gg} \mathrm{CO}_{2}$ equivalent per year which is also close to $40 \%$ of the local GHGE from electricity consumption in 2010. If more PV power stations of similar size were to be added to the local grid in the future in a proportion similar to that between consumption and the number of PV power stations authorised by 2013, there could be six such projects by 2030. At the time of writing, Aura Solar, has moved forward with construction and in fact has already started operations.

4) Other Measures in Electricity Consumption

In addition to the scenarios discussed above, the mitigation potential that lies with final users must not be neglected. Users have enormous influence through their appliance selection, usage patterns and user behaviour in general. This could be directed by means of incentives or penalties and user awareness and education campaigns as well as other demand management measures.

\subsection{Combined Mitigation Scenario: Transport and Electricity}

When the expected effects of the transport and electricity recommendations discussed above are added up, the mitigation curve presented in Figure 5 is obtained. This combination represents a total GHGE reduction of 343 $\mathrm{Gg} \mathrm{CO}_{2}$ equivalent by 2020 and of $715 \mathrm{Gg} \mathrm{CO}_{2}$ equivalent by 2030 . This equates to $18 \%$ and $30 \%$ reductions by 2020 and 2030, respectively, in relation to the BAU baseline. Nevertheless, despite the boldness of the measures proposed, GHGE levels by 2030 are still above those of 2010, although with decreasing trend.

\section{Final Remarks}

Due to its geographical location and coastal and arid conditions, the city of La Paz, Baja California Sur is extremely vulnerable to the adverse effects of global climate change on the use of natural resources, as well as on their productive activity and social and economic dynamics. Among the main potential impacts of climate change in the state are included the warming that threatens water resources and generates damage associated with coastal flooding; the presence of stronger cyclones; change in the course of streams; the loss of vegetation and soils leading to accelerated desertification; adverse impacts on biodiversity; negative impact in major economic sectors (fishery, tourism and agriculture); and increasing human vulnerability (disadvantaged social groups, employment, housing and health).

Nevertheless, the city of La Paz has great potential to enhance their chances of sustainability, reduce its vul- 


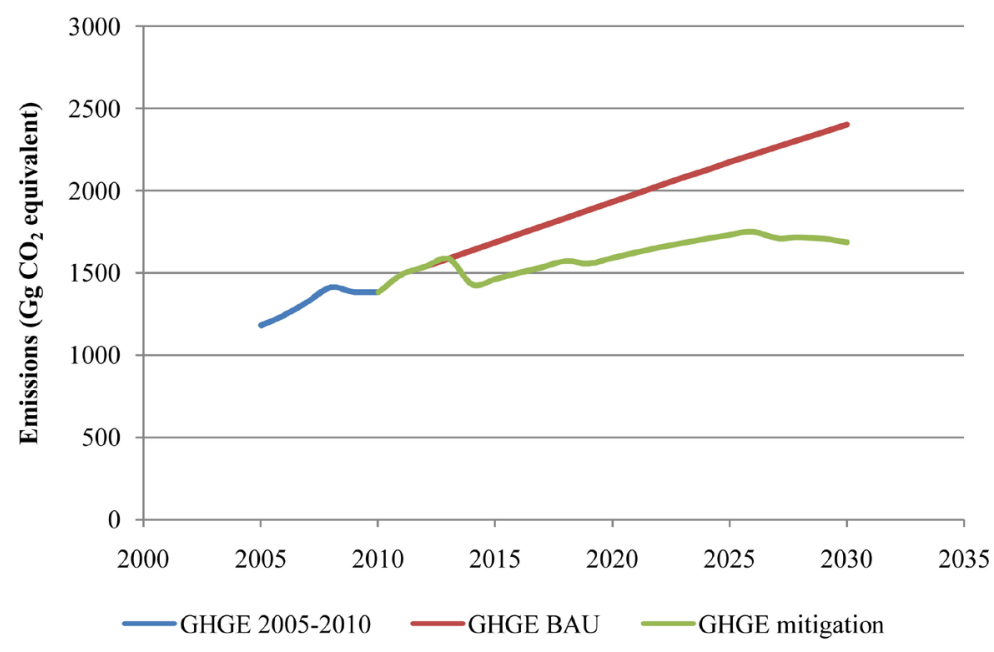

Figure 5. Total GHGE in BAU and combined mitigation scenarios.

nerability and improve the welfare of the population. Evidence of this are the advances in conservation actions, high public awareness and the existence of specialized human capital, as well as the participation of this capital in the ESCI of the IDB.

It is very important to note that both, mitigation and adaptation actions, have significant side effects directly related to priorities of the Municipal Development Plan (MDP): to establish effective policies for the management of scarce water resources; to improve public transport (routes and vehicle fleet); to protect vulnerable groups (because of their geographical location as well as because of their economic activities); to ensure a continued development in changing conditions of the main economic activities (fisheries and tourism), as well as to reduce dependence on these highly vulnerable to climate variability activities; to optimize the human, animal and plant health, among others.

The Climate Action Plan for the city of La Paz with its strategic lines of action is a valuable public policy tool to support decision makers at the state level in planning for mitigation actions of greenhouse gases and adaptation to the impacts of climate change as well as in broader sustainable development policies and raising of living standards for the local society.

\section{References}

Comisión Federal de Electricidad (CFE) (2012). Programa de Obras e Inversiones del Sector Eléctrico 2012-2026. http://www.cfe.gob.mx/ConoceCFE/1_AcercadeCFE/Paginas/Publicaciones.aspx

Comisión Federal de Electricidad (CFE) (2014). Programa de Obras e Inversiones del Sector Eléctrico 2014-2028.

Comisión Nacional del Agua (CONAGUA) (2011). Determinación de la disponibilidad de agua subterránea por acuífero en BCS. http://www.conagua.gob.mx/disponibilidad.aspx?id=Disponibilidad\%20por\%20acu\%C3\%ADfer

Comisión Nacional del Agua (CONAGUA) (2012). Consulta estadística del agua. http://www.conagua.gob.mx/CONAGUA07/Contenido/Documentos

Comisión Reguladora de Energía (CRE) (2012a). Título de permiso de pequeña producción de energía eléctrica núm. E-938-PP-2012. www.cre.gob.mx

Comisión Reguladora de Energía (CRE) (2012b). Título de permiso de pequeña producción de energía eléctrica núm. E-950-PP-2012. www.cre.gob.mx

Comisión Reguladora de Energía (CRE) (2013a). Título de permiso de pequeña producción de energía eléctrica núm. E-978-PP-2013. www.cre.gob.mx

Comisión Reguladora de Energía (CRE) (2013b). Título de permiso de pequeña producción de energía eléctrica núm. E-989-PP-2013. www.cre.gob.mx

Instituto Nacional de Ecología y Cambio Climático (INECC) (2013). Actualización de escenarios de cambio climático para México, como parte de los productos de la $5^{\circ}$ Comunicación Nacional.

http://escenarios.inecc.gob.mx/index2.html

Instituto Nacional de Estadística y Geografía (INEGI) (2010). Anuario Estadístico. México: Baja California Sur. 
http://cuentame.inegi.org.mx/monografias/informacion/bcs/economia/infraestructura.aspx?tema=me\&e=03

Instituto Nacional de Estadística y Geografía (INEGI) (2011a). Anuario de estadísticas por entidad federativa. www.inegi.org.mx/prod_serv/contenidos/espanol/bvinegi/productos/integracion/pais/aepef/2011/Aepef2011.pdf

Instituto Nacional de Estadística y Geografía (INEGI) (2011b). Vehículos de motor registrados en circulación por cada 100 habitantes. http://www3.inegi.org.mx/sistemas/biinegi/default.aspx

Intergovernmental Panel on Climate Change (IPCC) (1997a). Revised 1996 IPCC Guidelines for National Greenhouse Gas Inventories: Reporting Instructions (Vol. 1). IPCC. http://www.ipcc-nggip.iges.or.jp/public/gl/invs4.html

Intergovernmental Panel on Climate Change (IPCC) (1997b). Revised 1996 IPCC Guidelines for National Greenhouse Gas Inventories: Reporting Instructions (Vol. 2). IPCC. http://www.ipcc-nggip.iges.or.jp/public/gl/invs1.html

Intergovernmental Panel on Climate Change (IPCC) (1997c). Revised 1996 IPCC Guidelines for National Greenhouse Gas Inventories: Workbook (Vol. 3). IPCC. http://www.ipcc-nggip.iges.or.jp/public/gl/invs4.html

International Energy Agency (IEA) (2009). Transport, Energy and $\mathrm{CO}_{2}-$ Moving toward Sustainability. Paris: IEA. www.iea.org

Ivanova, A., \& Gámez, A. (Eds.) (2012). Plan Estatal de Acción ante el Cambio Climático para Baja California Sur. La Paz, México.

Ivanova, A., Bermúdez, A., de la Peña, A., de la Toba, D., Encarnación, E., Geiger, A., Gómez, I., Graciano, J. C., Juárez, E., René Kachok, R., López, C., Martínez, M., Martínez, V., Moreno, G., Petatán, D., Polanco, G., Ramírez, E., Rangel, E., Reyes, H., Rivera, J., \& Wurl (2013). Plan de Acción ante el Cambio Climático para La Paz y sus Áreas Colindantes. La Paz, México. http://www.lapaz.gob.mx/images/stories/cambioclima.zip

Kiy, R., \& McEnany, A. (2010). Tendencias sobre la jubilación de estadounidenses en las comunidades costeras de México, datos demográficos y prioridades en los estilos de vida, en International Community Foundation, serie de trabajos de investigación sobre la jubilación de estadounidenses en México, March, 20 p.

Moreno Gómez, G. (2012). Análisis del impacto del crecimiento de la mancha urbana en el ambiente biofísico del área conurbada de la ciudad de la paz, B.C.S., México. UABCS, Posgrado En Ciencias Sociales: Desarrollo Sustentable Y Globalización Tesina, Diciembre, La Paz, B.C.S., 38 p.

Organismo Operador Municipal del Sistema de Agua Potable y Alcantarillado de La Paz (OOMSAPA) (2012). Información del sistema de agua potable. http://www.lapaz.gob.mx/sapa/Enlaces/ConsyServ.htm

Páez Rosas, E. I. (2007). El espacio físico municipal, en Memoria de servicio social, Caracterización socioeconómica y demográfica del municipio de La Paz durante la última década del siglo XX y principios del siglo XXI: Un enfoque histórico. La Paz: Universidad Autónoma de Baja California Sur, 39-54.

Plan Municipal de Desarrollo (PMD) (2011). Diagnóstico Socioeconómico del Municipio de La Paz, Baja California Sur. H. XIV Ayuntamiento de La Paz, 159 p.

Secretaría de Agricultura, Ganadería, Desarrollo Rural, Pesca y Alimentación (SAGARPA) (2012). Datos Básicos de Baja California Sur, Subdelegación de Pesca, 157.

Secretaría de Medio Ambiente y Recursos Naturales (SEMARNAT) e Instituto Nacional de Ecología y Cambio Climático (INECC) (2012). México-Quinta Comunicación Nacional ante la Convención Marco de las Naciones Unidas sobre el Cambio Climático. Morelos: SEMARNAT.

Secretaría de Turismo (SECTUR) (2013). Directorio elaborado por el sistema de Información Turística Estatal (SITE).

Soriana (2013). Comunicado de prensa CP 10-2013: Soriana genera energía con paneles solares. http://publicidad.soriana.com/publicidad/resources/InfoInst/Sala_Prensa/2013/2013_05_07_Soriana_Genera_Energia_con _Paneles_Solares_10.pdf

Troyo-Diéguez, E., Cruz-Falcon, A., Aviles-Polanco, A., Beltran-Morales, L. F., Vega-Mayagoitia, J., Nieto-Garibay, A., Murillo-Amador, B., Alvaro-Gonzalez, M., Fraga-Palomino, H., Wurl, J., Zamora-Salgado, S., Beltrán-Morales, F. A., Ruiz-Espinoza, F., Troyo-Dieguez, S., Nava-Sanchez Carrillo, E., \& Frias-Villagon, F. (2010). Plan de Manejo Integrado de las Aguas Subterráneas en el Acuífero La Paz, Baja California Sur TOMO I.-Convenio No. SGT-OCPBC-BCS-10-GAS001-CONV-Centro de Investigaciones Biologicas del Noroeste, S.C., La Paz, Baja California Sur. Diciembre de 2010,222 p.

UN-Habitat (2010). Planning for Climate Change: A Resource Guide for Urban Planners (draft, 2010).

United Nations Environment Programme (UNEP) (2008). Metodología para la elaboración de los informes GEO Cities. Manual de aplicación. Versión 3.

United Nations Environment Programme (UNEP) (2009). Training Manual on Vulnerability and Adaptation to Climate Change for Geo Cities.

United Nations Environment Programme (UNEP) (2011). IEA Training Manual, Climate Change Vulnerability and Impact Assessment in Cities. http://www.unep.org/ieacp/files/pdf/Climate/IEA-Climate-Change-VIA-City.pdf 
World Bank (2013). Motor Vehicles (per 1,000 People). http://data.worldbank.org/indicator/IS.VEH.NVEH.P3

Wurl, J., \& Martínez Gutiérrez, G. (2006). El efecto de ciclones tropicales sobre el clima en la cuenca de Santiago, Baja California Sur, México. III Simposio Internacional en Ingeniería y Ciencias para la Sustentabilidad Ambiental y Semana del Ambiente, México, DF, 5-6 de junio. 
Scientific Research Publishing (SCIRP) is one of the largest Open Access journal publishers. It is currently publishing more than 200 open access, online, peer-reviewed journals covering a wide range of academic disciplines. SCIRP serves the worldwide academic communities and contributes to the progress and application of science with its publication.

Other selected journals from SCIRP are listed as below. Submit your manuscript to us via either submit@scirp.org or Online Submission Portal.
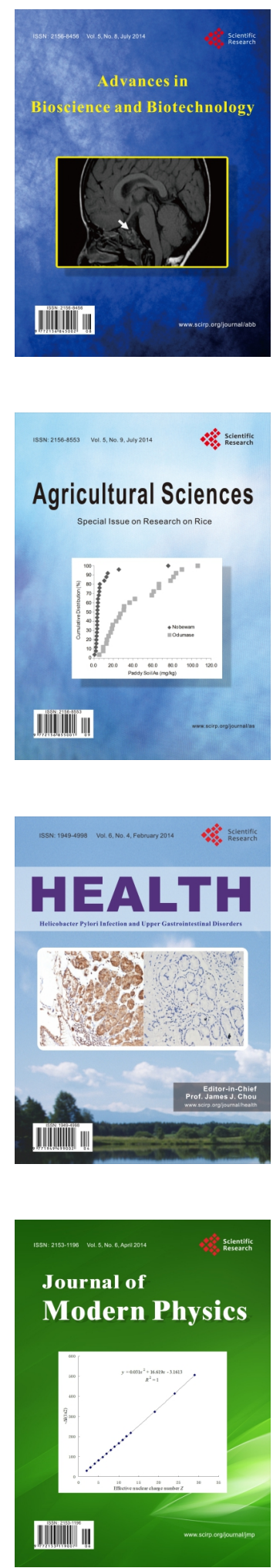
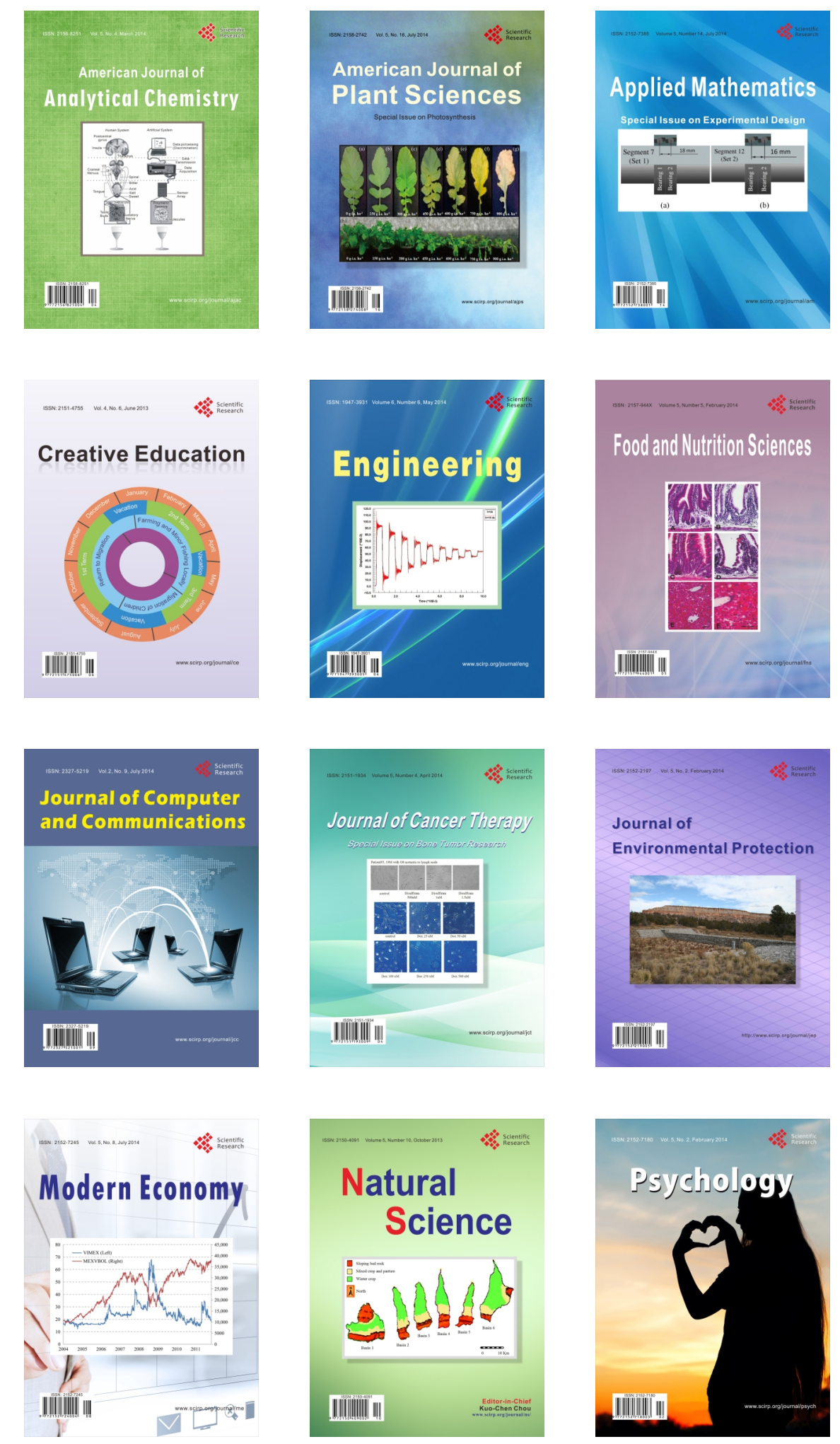